\section{Changes of physical properties of asphalt aggregates by heat. A laboratory study.}

GABRIELLA DEVECSERI - Department of Highway and Railway Engineering, BME devecseri@uvt.bme.hu Érkezett: 2009.06.04. - Received: 04.06.2009. http://dx.doi.org/10.14382/epitoanyag-jsbcm.2010.5

Asphalt mixtures can meet with several different temperatures during their life cycle. The effects of high temperatures on asphalt aggregates have not been examined in detailes yet. Two temperatures were choosen $\left(240^{\circ} \mathrm{C}\right.$ and $\left.480^{\circ} \mathrm{C}\right)$ to be examined. Aggregates meet with $240^{\circ} \mathrm{C}$ temperature in case of mastix asphalt, and $480^{\circ} \mathrm{C}$ temperature during asphalt binder analysis. High temperatures cause changes in the physical properties of aggregates that are commonly used in asphalt mixtures. To asses these changes 11/16 mm fractions of three different types (andesite, basalt and dolomite) of Hungarian aggregates were tested in the laboratory by submitting the samples to heating at $240^{\circ} \mathrm{C}$ and at $480^{\circ} \mathrm{C}$. The loss of masses, and particle size distributions coloures and colour differences were recorded and compared. The physical parameters have shown that aggregates behave differently after burning on different temperatures and uniform trends could not be discovered between the type of aggregate, the mechanical properties and thermophysical behaviour of aggregates.

Keywords: high temperature, asphalt aggregates, physical properties, thermophysical behaviour
Gabriella DEVECSERI (1980) MSc Civil Eng. at BME in 2004. From 2004 to 2005 Regional Research Centre NGO, civil engineer, project manager. From 2005 to 2008 PhD Student at Dept. of Highway and Railway Engineering, BME. From 2008 to 2009 civil engineer and lecturer at Dept. of Highway and Railway Engineering, BME. In Year 2009 at Dept. of Highway and Railway Engineering, BME, research fellow. Member of the Hugarian Scientific Association for Transport; Environmental Management and Law Association. Field of interests: asphalt binder analysis, environmental protection.

\section{Introduction}

Asphalt is defined as a mixture of inert mineral matter, such as aggregate, mineral filler and bituminous binder in predeterminated portions.

Aggregates have been used as pavement materials since prehistoric time. Aggregates of asphalt mixtures can be different depending on the location of the constructed road.

Thermal behaviour of aphalt mixtures have been examined previously [6] [8], but the thermal behaviour of aggregates themselves, especially the effect of high temperature on asphalt aggregates has not been examined in details yet.

Two temperatures were choosen $\left(240^{\circ} \mathrm{C}\right.$ and $\left.480^{\circ} \mathrm{C}\right)$ to be examined. Aggregates meet with $240^{\circ} \mathrm{C}$ temperature in case of mastix asphalt, and $480^{\circ} \mathrm{C}$ temperature in the quality control practice, in case of asphalt binder analysis (but fire hazards can also cause high temperatures). Very few attempts have been made to understand how these stones behave under different temperatures, especially under high temperatures.

My aim was to collect more knowledge from the behaviour of Hungarian asphalt aggregates.

\section{Experimental methods}

The effect of heat was studied on three Hungarian stone types. $11 / 16 \mathrm{~mm}$ fractions were examined. $10 \times 1000 \mathrm{~g}$ portions were prepaired from each rock type for burning. Test portions in steel basket were placed in the furnace. The portions were heated in a special oven (ABA/75 Carbolite Asphalt Binder Analyser) at $240^{\circ} \mathrm{C}$ and at $480^{\circ} \mathrm{C}$ while mass loss was recorded until the mass become constant. The ignition furnace consists of a combustion chamber with an integral balance located below. The balance contains software to monitor the rate of mass loss during the test. Once the sample has reached a predetermined constant mass point the test is automatically stopped.
After heating the portions were cooled down on $22^{\circ} \mathrm{C}$ to become ready for sieving. In each case sieving took for half an hour (hole sizes of sieves were the followings: $0 \mathrm{~mm}, 0,063$ $\mathrm{mm}, 0,125 \mathrm{~mm}, 0,250 \mathrm{~mm}, 1 \mathrm{~mm}, 2 \mathrm{~mm}, 4 \mathrm{~mm}, 5,6 \mathrm{~mm}, 8$ $\mathrm{mm}, 11,2 \mathrm{~mm}$ ). The particle size distribution of the burned portions was measured after sieving. After the end of the examination $2 \times 3 \times 10$ particle size distribution and mass loss data were available for the analysis.

Photographs were also made before and after heating.

\subsection{Description of stones}

Asphalt aggregates are those materials used in asphalt pavements. Three Hungarian aggregate types correspond to the most widely used pavement stones in this country were choosen to be tested under different circumstances. The most important parameters of studied aggregates are given in Table 1.

\begin{tabular}{|c|c|c|c|c|c|c|}
\hline Nr. & Origin & Type & $\begin{array}{c}\text { Colour } \\
\text { at } \\
22^{\circ} \mathrm{C}\end{array}$ & $\begin{array}{l}\text { Typical } \\
\text { Minerals }\end{array}$ & $\begin{array}{c}\text { Bulk } \\
\text { Density } \\
{\left[\mathrm{kg} / \mathrm{m}^{3}\right]}\end{array}$ & $\begin{array}{c}\text { Los } \\
\text { Angeles } \\
{[\mathrm{m} \%]}\end{array}$ \\
\hline 1. & Tállya & Andesite & $\begin{array}{l}\text { Greyish } \\
\text { black }\end{array}$ & $\begin{array}{c}\text { Plagioclase, } \\
\text { Amfibole, } \\
\text { Piroxene, } \\
\text { Biotite }\end{array}$ & 2650 & 19,07 \\
\hline 2. & Uzsa & Basalt & $\begin{array}{c}\text { Greyish } \\
\text { black }\end{array}$ & $\begin{array}{l}\text { Plagioclase, } \\
\text { Piroxen, } \\
\text { Olivine }\end{array}$ & 2750 & 13,23 \\
\hline 3. & $\begin{array}{l}\text { Iszkaszent- } \\
\text { györgy }\end{array}$ & Dolomite & Jonquil & Dolomite & 2750 & 17,70 \\
\hline
\end{tabular}

Table 1. Most important parameters of examined aggregates

1. táblázat A vizsgált közetek legfontosabb tulajdonságai 
Hungary is rich in dolomite, but the effusive rock sources of the country are limited (especially basalt) so the knowledge of the mechanical and thermal behaviour of different aggregates is fundamental for the pavement design and for mining. As Hungary has dolomite resources in a high ammount some researchers started to go on to discover whether asphalts with dolomite aggregates can reach the same quality as other mixtures, or could they be used somehow as pavement material.

This laboratory testing can provide valuable information on thermal behaviour of aggregates.

\section{Results}

Three types of changes in physical properties have been observed, and evaluated after testing:

- changes in particle size distribution,

- changes of mass and

- colour changes.

\subsection{Changes in particle size distribution}

According to the laboratory tests after burning the speciments on $240^{\circ} \mathrm{C}$ and on $480^{\circ} \mathrm{C}$ notable changes have been appeared in the particle size distribution of the stones. Small pieces broke down from the $11 / 16 \mathrm{~mm}$ fractions as the result of heating. In Fig. 1-5. particle size distributions of the examined rocks are represented (the end of the diagrams of particle size distributions has been cut off as the percentage passing reaches $100 \%$ above $11,2 \mathrm{~mm}$ in each case). Particle size distributions were compared after heating at different temperatures in case of each type of stones, and the particle size distributions of the different type of stones were also compared with each other.

After heating at $240^{\circ} \mathrm{C}$ weathering of Tállya andesite varied between $0,08-1,15 \%$. This is less than the weathering of this type of stone after heating at $480{ }^{\circ} \mathrm{C}$ where the minimum was $0,35 \%$ and the maximum $1,77 \%$. The average of weathering after heating at $240{ }^{\circ} \mathrm{C}$ was $0,60 \%$, while after heating at $480^{\circ} \mathrm{C}$ it was $1,27 \%$. Deviation of the measured values was $0,36 \%$ $\left(240^{\circ} \mathrm{C}\right)$ and $0,45 \%\left(480^{\circ} \mathrm{C}\right)$.

In case of Iszkaszentgyörgy dolomite results were different. After heating at $240^{\circ} \mathrm{C}$ weathering of Iszkaszentgyörgy dolomite varied between $0,99-2,70 \%$. Average of the results was $1,58 \%$ and the deviaton was $0,64 \%$. Weathering of Iszkaszentgyörgy dolomite reached $0,59-1,39 \%$ after heating at $480^{\circ} \mathrm{C}$. Average of the results was $0,95 \%$. Deviation of the values was $0,30 \%$. What is interesting in these results is the opposite relation. While the temperature increased weathering decreased.

The same happened in case of Uzsa basalt where the results of weathering varied between $0,51-2,78 \%$ after heating at $240^{\circ} \mathrm{C}$. Average was $1,34 \%$ and deviation $0,75 \%$. After heating at $480^{\circ} \mathrm{C}$ $0,32-2,23 \%$ of weathering was measured. Average of particle size distributions was $1,63 \%$ while deviation was $0,62 \%$.

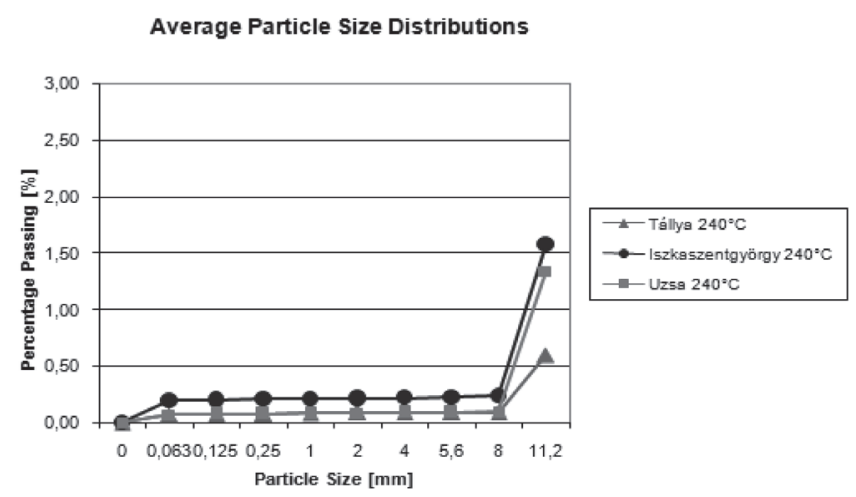

Fig. 1. Average particle size distributions of aggregates after heating 11/16 mm fractions at $240^{\circ} \mathrm{C}$

1. ábra A vizsgált kőzetek szemmegoszlás átlagai $240^{\circ} \mathrm{C}$-on történő égetést követően

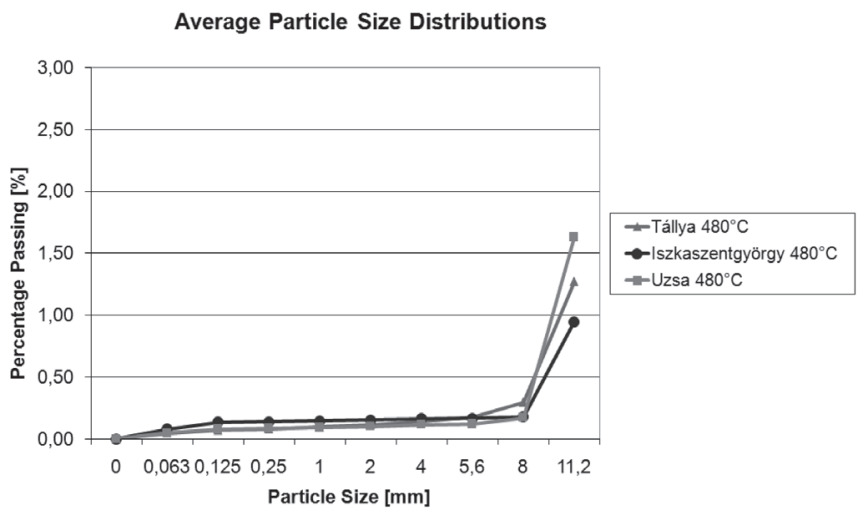

Fig. 2. Average particle size distributions of aggregates after heating $11 / 16 \mathrm{~mm}$ fractions at $480^{\circ} \mathrm{C}$

2. ábra A vizsgált közetek szemmegoszlás átlagai $480^{\circ} \mathrm{C}$-on történö égetést követően

Average Particle Size Distributions

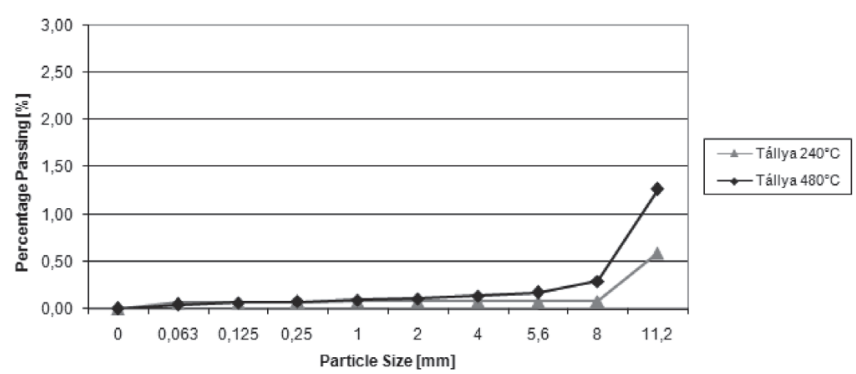

Fig. 3. Average particle size distributions of Tállya andesite after heating $11 / 16 \mathrm{~mm}$ fractions at $240^{\circ} \mathrm{C}$ and $480^{\circ} \mathrm{C}$

3. ábra A tállyai andezit szemmegoszlás átlagai $240^{\circ} \mathrm{C}$-on, valamint $480^{\circ} \mathrm{C}$-on történö égetést követően

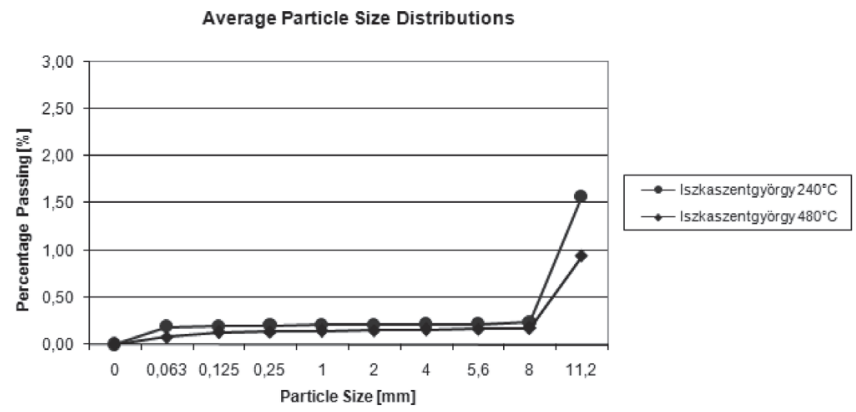

Fig. 4. Average particle size distributions of Iszkaszentgyörgy dolomite after heating $11 / 16 \mathrm{~mm}$ fractions at $240^{\circ} \mathrm{C}$ and $480^{\circ} \mathrm{C}$

4. ábra Az iszkaszentgyörgyi dolomit szemmegoszlás átlagai $240^{\circ} \mathrm{C}$-on, valamint $480^{\circ} \mathrm{C}$-on történó égetést követően 


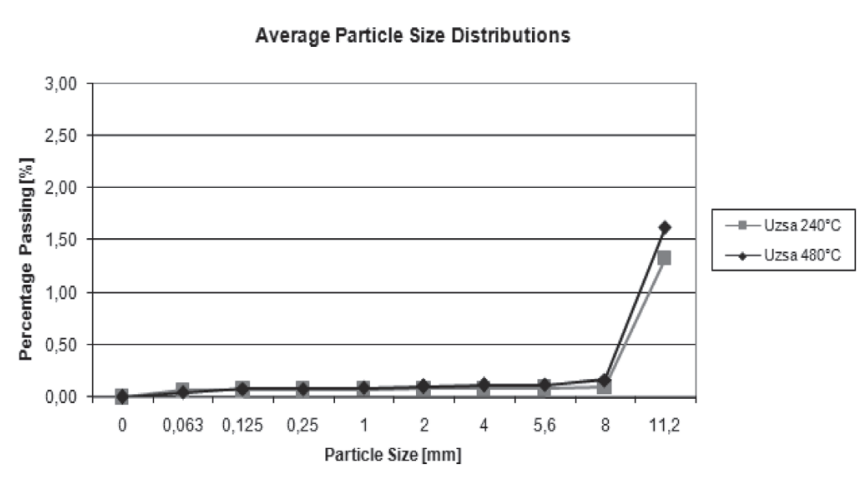

Fig. 5. Average particle size distributions of Uzsa basalt after heating $11 / 16 \mathrm{~mm}$ fractions at $240{ }^{\circ} \mathrm{C}$ and $480^{\circ} \mathrm{C}$

5. ábra Az uzsai bazalt szemmegoszlás átlagai $240^{\circ} \mathrm{C}$-on valamint, $480^{\circ} \mathrm{C}$-on történö égetést követően

\subsection{Loss in mass}

The laboratory test has shown that the examined stones change their mass during burning on $480^{\circ} \mathrm{C}$ but loss in mass has not been appeared at $240^{\circ} \mathrm{C}$ (Fig. 6. and Table 2.). In case of Tállya andesite the minimum of mass loss was $0,80 \%$ and the maximum $0,92 \%$. In case of Uzsa basalt this rate was higher. The biggest mass loss was measured in case of this type of stone. The maximum was $1,10 \%$ and the minimum was $0,97 \%$ which is higher than the maximum of Tállya andesite. According to the experiment mass loss in case of dolomite has not been measured. On the contrary although in a very little rate $(0,01 \%)$ but mass of dolomite has decreased after heating.

\subsection{Colour changes}

An additional result of the laboratory tests was the colour change of aggregates (Table 3.). After heating at $240^{\circ} \mathrm{C}$ colour changes of stones were not observable but some of the aggregates show very distinct colour changes after heating at $480^{\circ} \mathrm{C}$ which was visible to the naked eye. At room temperature the colour of dolomite is yellowish (jonquil) but after heating at $480^{\circ} \mathrm{C}$ this colour turned to pinkish. Andesite and basalt has greyish black colour at $22^{\circ} \mathrm{C}$ but this colour also transforms to reddish or to brownish. For the question of colour changes has mineralogical answers.

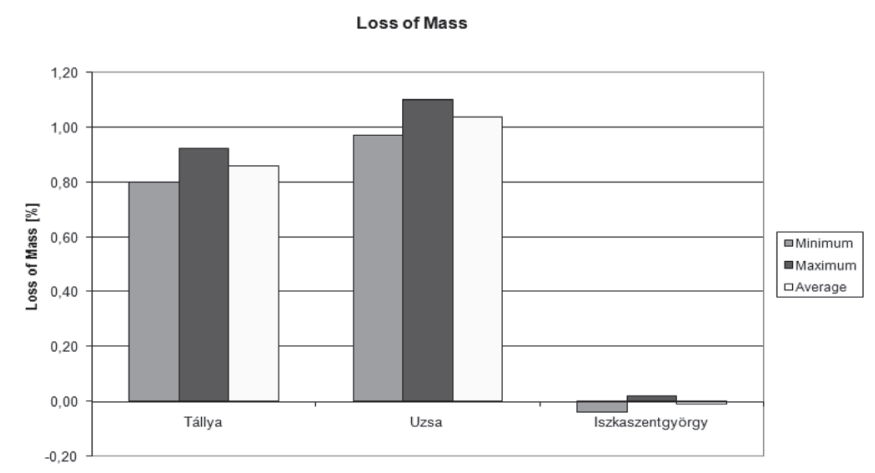

Fig. 6. Mass losses of aggregates after heating at $480^{\circ} \mathrm{C}$

6. ábra A vizsgált közetek $480^{\circ} \mathrm{C}$-on történö égetés hatására bekövetkezö tömegvesztesége

\section{Discussion}

$240^{\circ} \mathrm{C}$ and $480^{\circ} \mathrm{C}$ temperatures although in different quantities but in both cases cause changes in the original particle size distributions of the stones because of weathering.

There is no relation between the ammount of weathering and the type of aggregate.

According to the comparison of particle size distributions with the Los Angeles values relation could not be discovered beween the mechanical and the thermophysical behavour of the stones.

It was expected that weathering of dolomite is more than the weathering of effusive rocks as they known as less lasting stones, but trend could not be discovered.

In these experiments not only thermal breaks has been documented but also changes in mass of aggregates. $240^{\circ} \mathrm{C}$ temperature has not caused chanes in the original mass of samples. But after heating at $480^{\circ} \mathrm{C}$ mass losses were recorded for effusive rocks, and constant mass, or mass growing for dolomite. This suggest that the sedimentary rocks can absorb air moisture during heating, while in effusive rocks organic parts, or minerals burn out.

Higher temperature caused higher weathering in case of andesite rocks, but dolomite and basalt had less weathering in case of $480^{\circ} \mathrm{C}$. The reason of this could be the cohesion of grains. These experiments have shown that type of aggregates do not necessarily show a uniform behaviour.

\begin{tabular}{|c|c|c|c|c|c|c|c|}
\hline \multirow[t]{2}{*}{ Origin } & \multirow[t]{2}{*}{ Type } & \multirow[t]{2}{*}{$\begin{array}{c}\text { Number of } \\
\text { samples [pieces] }\end{array}$} & \multirow[t]{2}{*}{$\begin{array}{c}\text { Mass Loss } \\
{[\mathrm{m} \%] \text { at } 240^{\circ} \mathrm{C}}\end{array}$} & \multicolumn{4}{|c|}{ Mass Loss $\left[\mathrm{m} \%\right.$ ] at $480^{\circ} \mathrm{C}$} \\
\hline & & & & Average & Deviation & Minimum & Maximum \\
\hline Tállya & Andesite & $2 \times 10$ & 0 & 0,86 & 0,04 & 0,80 & 0,92 \\
\hline Uzsa & Basalt & $2 \times 10$ & 0 & 1,04 & 0,04 & 0,97 & 1,10 \\
\hline Iszkaszentgyörgy & Dolomite & $2 \times 10$ & 0 & $-0,01$ & 0,02 & $-0,04$ & 0,02 \\
\hline
\end{tabular}

Table 2. Mass losses of aggregates

2. táblázat Kövázak égetés hatására bekövetkezö tömegvesztesége

\begin{tabular}{|c|c|c|c|c|}
\hline \multirow[t]{2}{*}{ Origin } & \multirow[t]{2}{*}{ Type } & \multicolumn{3}{|c|}{ Colour at } \\
\hline & & $22^{\circ} \mathrm{C}$ & $240^{\circ} \mathrm{C}$ & $480^{\circ} \mathrm{C}$ \\
\hline Tállya & andesite & greyish black & greyish black & reddish grey \\
\hline Uzsa & basalt & greyish black & greyish black & brownish \\
\hline Iszkaszentgyörgy & dolomite & jonquil & jonquil & pinkish \\
\hline
\end{tabular}

Table 3. Colour changes of aggregates after heating at $240{ }^{\circ} \mathrm{C}$ and $480^{\circ} \mathrm{C}$

3. táblázat A vizsgált közetek $240^{\circ} \mathrm{C}$ és $480^{\circ} \mathrm{C}$ hatására bekövetkezö makroszkópos színváltozása 
During these examinations macroscopic colour changes were also documented. After heating at $240^{\circ} \mathrm{C}$ macroscopic colour changes have not been discovered. Changes were observed both on effusive and sedimentary rocks after heating at $480^{\circ} \mathrm{C}$. It depends on the mineralogical contents of the stones whether their original colours change during heating. The most common was the transformation of the original colour to reddish, which is the result of the transformation of ferrooxids, but the transformation of mangan and organic parts can cause colour changes too [3].

When iron is present as ferri-oxy-hydroxid (goethite) it often transforms to ferro-oxid (hematite), while the water dissapears. Changes start at $200-300^{\circ} \mathrm{C}$ [2] [3]. Transformation of organic parts to carbon starts at arround $500^{\circ} \mathrm{C}$ [2] [3].

\section{Conclusions}

The most important establishments in relation with the thermophysical behaviour of aggregates are the followings:

1. High temperature $\left(480^{\circ} \mathrm{C}\right)$ causes minearlogical and physical changes in the asphalt aggregates.

2. $240^{\circ} \mathrm{C}$ temperature does not have significant influence on the mass losses and the mineralogical changes of asphalt aggregates.

3. Weathering of aggregates was observed in case of both temperatures. In case of $240^{\circ} \mathrm{C}$ weathering of stones was less than $1,10 \%$. Heating rocks at $480^{\circ} \mathrm{C}$ causes less than $3 \%$ weathering in case of $11 / 16 \mathrm{~mm}$ fractions of examined aggregates.

4. Higher temperature caused higher weathering in case of andesite rocks, but dolomite and basalt had less weathering after submitting to $480^{\circ} \mathrm{C}$.

5. Effusive rocks have mass losses during heating at $480^{\circ} \mathrm{C}$, because organic or mineral parts burn out, while near the same circumstances mass of dolomite stayes constant.

6. It can not be stated that effusive rocks have better quality than the sedimentary rocks, at least according to their thermophysical behaviour.

7. There is no relation between the Los Angeles values and the thermophysical behaviour of aggregates.

8. Indirectly lasting of pavements depends also on the thermophysical properties of aggregates, not only on the mechanical properties.

9. Colour changes were observed as additional results of the analysis. The aggregates have changed their colours after burning at $480^{\circ} \mathrm{C}$. Heating of stones at $240^{\circ} \mathrm{C}$ has not caused macroscopic changes in the original colour of the samples.

References

[1] Balázs Gy. - Buda Gy. - Borján J. - Kertész P. - Kovács M. - Liptay A. - Zimony Gy. (1975): Épitököveink vizsgálata útépitési alkalmasság szempontjából, Tudományos Közlemények 20. Közlekedési Dokumentációs Vállalat, Budapest, pp 8-9;184

[2] Hajpál M. - Török Á. (2004): Mineralogical and colour changes of quartz sandstones by heat. Environmental Geology 46, pp 311-322

[3] Hajpál M. (2008): Hevités indukálta színváltozás természetes kőanyagoknál, épitőköveknél, Mérnökgeológia Közetmechanika 2008, Müegyetemi Kiadó, Budapest, pp 145-157

[4] Hajpál M. - Török Á. (1998): Petrophysical and mineralogical studies of burnt sandstones, 2nd Int. PhD Symposium in Civil Engineering, Budapest, pp 476-484
[5] Hans G. Schreuders - Charles R. Marek (1989): Implication of aggregates in the design, construction, and performance of flexible pavements, ASTM International

[6] Isacsson U. - Huayang Zeng (1997): Relationships between bitumen chemistry and low temperature behaviour of asphalt, Construction and Building Materials, Vol.11, No 2, pp 83-91

[7] Kertész P. (1970): Közetfizika, Tankönyvkiadó, Budapest, pp 140-143

[8] Palade LI. - Attané P. - Camaro S. (2000): Linear viscoelastic behavior of asphalt and asphalt based mastic, Rheol Acta, 39, Springer-Verlag 2000, pp 180-190

[9] Papp F. - Kertész P. (1975): Geológia, Tankönyvkiadó, Budapest, pp 78-82; 114

[10] Richard C. Meininger (1992): Asphalt Mixture Performance, ASTM International

[11] Török Á. (2007): Mérnökgeológia mérnököknek, Műegyetemi Kiadó, Budapest, pp 81; 199-200; 294-295; 297-298

[12] Török Á. - Hajpál M. (2005): Effect of Temperature Changes on the Mineralogy and Physical Poperties of Sandstones. A Laboratory Study. Restoration of Buildings and Monuments. Vol. 11, No 4, pp 211-218

\section{Az aszfaltkeverékek jellemző kővázainak égetés}

\section{hatására bekövetkező fizikai változásai}

Az útépítés aszfaltkeverékeit különbözố nagyságú hốmérsékletek érik a gyártás, illetve a minôségellenôrzés során. Az öntött aszfalt hômérséklete eléri a $220-240{ }^{\circ} \mathrm{C}$-ot, míg a minôségellenôrzố vizsgálatok közül a bitumentartalom égetéssel történố meghatározását $480-540{ }^{\circ} \mathrm{C}$ magas hômérsékleten végzik. Az aszfaltkeverékeket alkotó kôvázak fizikai tulajdonságaiban magas hômérséklet hatására bekövetkezô változások mélyreható vizsgálatára korábban nem került sor. Jelen kísérlet sorozat három különbözô kôzet típus (andezit, bazalt, dolomit) meghatározott frakciójának (11/16 mm) két különbözố hốmérsékleten $\left(240^{\circ} \mathrm{C}\right.$-on és $480^{\circ} \mathrm{C}$-on) való viselkedését követi szemmel. A laborvizsgálat során az ásványi vázak eredeti tömegében bekövetkezố változások, az eredeti frakció szemmegoszlás változása, valamint a kôzetek makroszkopikus színváltozása került dokumentálásra. Az ásványi vázak az égetés során egészen eltérô viselkedést mutattak, így a kôvázak termofizikai viselkedése és mechanikai viselkedése között határozott összefüggésekre nem lehetett következtetni.

Kulcsszavak: magas hốmérséklet, aszfalt, kôváz, fizikai tulajdonságok

\section{PROGRAMAJÁNLÓ}

\section{Üvegipari Szakmai Konferencia}

2010. május 5-én szervezi szokásos tavaszi konferenciáját az Üveg Szakosztály.

A rendezvénynek ezúttal a GE Hungary Kft. ad otthont. A gyárlátogatással egybekötött konferencián elsốsorban a Tungsram és a GE közös történetérốl, valamint aktuális termékfejlesztésekrôl lesz szó.

\section{Európai Bányász Kohász Találkozó 8. Magyar Bányász Kohász Erdész Találkozó Pécs, 2010. május 27-30.}

Az Európai Bányász Kohász Szövetség (VEBH), az Országos Magyar Bányászati és Kohászati Egyesület (OMBKE) és Pécs város Önkormányzata tisztelettel meghivja az európai bányász-kohász szakembereket és a bányász- kohász hagyományôrzố szervezeteket a 13. Európai Bányász Kohász Találkozó rendezvényeire, mely egyúttal a 8. Magyar Bányász Kohász Erdész Találkozó is. A rendezvénysorozat központi helyszíne Pécs városában az EXPO CENTER.

További információ: www.ombkenet.hu 